\title{
Active smoking and risk of breast cancer in a Danish nurse cohort study
}

\author{
Zorana Jovanovic Andersen ${ }^{1 *}$, Jeanette Therming Jørgensen ${ }^{1}$, Randi Grøn', Elvira Vaclavik Brauner ${ }^{2,3}$ \\ and Elsebeth Lynge ${ }^{1}$
}

\begin{abstract}
Background: No scientific consensus has been reached on whether active tobacco smoking causes breast cancer. We examine the association between active smoking and breast cancer risk in Denmark, which has some of the highest smoking and breast cancer rates in women worldwide.

Methods: We used the data from a nationwide Danish Nurse Cohort on 21,867 female nurses (age $>44$ years) who at recruitment in 1993 or 1999 reported information on smoking status, onset, duration, and intensity, as well as breast cancer risk factors. We obtained data on incidence of breast cancer from Danish Cancer Registry until 2013, and used Cox regression models to analyze the association between smoking and breast cancer.

Results: Of 21,831 women (mean age 53.2 years) 1162 developed breast cancer during 15.7 years of follow-up. 33. $7 \%$ of nurses were current and 30.0\% former smokers at cohort baseline. Compared to never smokers, we found increased risk of breast cancer of 18\% in ever (hazard ratio and 95\% confidence interval: 1.18; 1.04-1.34) and 27\% in current $(1.27 ; 1.11-1.46)$ smokers. We detected a dose-response relationship with smoking intensity with the highest breast cancer risk in women smoking $>15 \mathrm{~g} /$ day $(1.31 ; 1.11-1.56)$ or $>20$ pack-years $(1.32 ; 1.12-1.55)$. Parous women who smoked heavily (>10 pack-years) before first childbirth had the highest risk of breast cancer $(1.58 ; 1.20-2.10)$. Association between smoking and breast cancer was not modified by menopausal status, obesity, alcohol or hormone therapy use, and seemed to be limited to the estrogen receptor positive breast cancer subtype.
\end{abstract}

Conclusions: Active smoking increases risk of breast cancer, with smoking before first birth being the most relevant exposure window.

Keywords: Tobacco smoking, Active smoking, Breast cancer, Cohort

\section{Background}

Tobacco smoke is the leading cause of cancer worldwide and contains over 4000 known carcinogenic substances. [1] No scientific consensus has been reached on whether active tobacco smoking causes breast cancer, despite 25 years of debate and over 150 epidemiological studies. $[2,3]$ Smoking has been suggested to have an antiestrogenic effect [4] and should thus be expected to protect against breast cancer in post-menopausal women. However, a meta-analysis of 53 epidemiological studies found no impact of smoking on the risk of breast cancer. [5] Early studies on smoking and breast cancer risk have

\footnotetext{
* Correspondence: zorana.andersen@sund.ku.dk

${ }^{1}$ Centre for Epidemiology and Screening, Department of Public Health, University of Copenhagen, Øster Farimagsgade 5, 1014 Copenhagen, Denmark

Full list of author information is available at the end of the article
}

however been criticized for their crude definitions of smoking and lack of information on intensity, duration, and onset, or use of hospital based controls in casecontrol studies, which may explain the null associations reported. [5]

Recent large prospective cohort studies [6-13] with detailed data on active smoking consistently report an increased breast cancer risk associated with longer duration and higher intensity of smoking, and indicating that smoking early in life, before first childbirth, is the most relevant exposure window. $[6,7,9,11]$ Still, some inconsistencies exist as not all recent studies linked active smoking to breast cancer. [14, 15] The latest reports from the International Agency for Research on Cancer (IARC) [1] and the US Surgeon General [3] conclude that there was suggestive, but insufficient, evidence to 
infer a causal relationship between active smoking and breast cancer, [3] calling for more data.

In Denmark, with some of the highest smoking prevalence and breast cancer incidence in the world, the impact of smoking on breast cancer has been debated due to conflicting results from the early Danish studies. [16, 17] More recently, no association between smoking and breast cancer was detected in 28,000 women from Danish Diet, Cancer and Health cohort which formed part of the large European Prospective investigation into Cancer and Nutrition (EPIC) study. [11] In the EPIC study, the observed overall positive association between smoking and breast cancer was driven by data from the other non-Danish EPIC cohorts. [11] On this basis, we investigated the association between active smoking and breast cancer risk in members of the Danish Nurse Cohort, which is a large, nationwide cohort of female nurses older than 44 years.

\section{Methods}

\section{The Danish nurse cohort}

The Danish Nurse Cohort [18] was inspired by the American Nurses' Health Study to initially investigate the health effects of hormone therapy (HT) in a European population. The cohort was initiated in 1993 by sending a questionnaire to 23,170 female Danish nurses (> 44 years), members of the Danish Nursing Organization, which included $95 \%$ of all nurses in Denmark. In total, 19,898 (86\%) nurses replied, and the cohort was reinvestigated in 1999, including an additional 10,534 nurses (who turned 44 years in the period 1993-99), of whom 8833 (84\%) replied. Nurses filled out the questionnaire at recruitment on working conditions, weight and height, lifestyle (diet, active smoking, alcohol consumption, and leisure time physical activity), parity, age at first birth, age of menarche and menopause, and use of oral contraceptives (OC) and HT. We utilized baseline information from $1993(19,898)$ or 1999 (8833) for 28,731 female nurses. Using a unique identification number we linked the cohort participants to Civil Registration System [19] to obtain vital status information at 31st December 2012 (active, date of death or emigration).

\section{Active tobacco smoking}

Data on active tobacco smoking were obtained from the baseline questionnaire in 1993 or 1999, and included questions on smoking status (never/former/current), smoking duration (years), age at smoking onset (years), average number of cigarettes, cheerots, and cigars smoked per day, and on smoking a pipe (yes/no) in ever smokers. Based on this information we calculated smoking intensity in $\mathrm{g}$ /day by equating a cigarette to $1 \mathrm{~g}$, a cheroot to $3 \mathrm{~g}$, and a cigar to $4.5 \mathrm{~g}$ of tobacco, and pack-years of smoking by multiplying the number of packs per day ( 1 pack $=20 \mathrm{~g})$ and the number of years smoked. We defined onset of smoking before and after 1st birth in parous women and age of 21 years (mean age of smoking initiation in the cohort) in nulliparous women. Pack-years of smoking before 1st childbirth, between 1st childbirth and menopause, and after menopause was calculated from information on age of smoking onset, age at 1st birth, and age at menopause in parous postmenopausal women. No information was collected on passive smoking in the Danish Nurse Cohort.

\section{Breast cancer definition}

We linked the records of 28,731 nurses using unique identification number to the Danish Cancer Register [20] to extract all cancer diagnoses until 2013. First, we extracted data for nurses with diagnoses for any (other than non-melanoma skin cancer) cancer before baseline (1st April 1993 or 1st April 1999), these nurses were excluded from the analyses. Secondly, among nurses without prior cancer, we extracted primary invasive breast cancer diagnoses (ICD-10 codes C50), as the main outcome, and any other cancer (other than non-melanoma skin cancer) between cohort baseline (1st April 1993 or 1st April 1999) and 31st December 2012. Furthermore, we extracted data on breast cancer subtype by estrogen receptor (ER) and progesterone receptor (PR) status from the clinical database of the Danish Breast Cancer Cooperative Group. [21]

\section{Statistical analyses}

We used Cox proportional hazards regression with age as the underlying time, to investigate the association between smoking and breast cancer in a crude model (age adjusted as age is underlying time scale), and in a fully adjusted model, adjusted for age at the time of recruitment, birth cohort (1990-1934; 1935-1944; 1945-1949; 1950-1955), Body Mass Index (BMI) $\left(<18.5 \mathrm{~kg} / \mathrm{m}^{2}\right.$; $\left.18.5-25 \mathrm{~kg} / \mathrm{m}^{2} ; 25-30 \mathrm{~kg} / \mathrm{m}^{2} ; \geq 30 \mathrm{~kg} / \mathrm{m}^{2}\right)$, alcohol use (none; moderate (1-14 drinks/week); heavy (>15 drinks/ week)), leisure time physical activity (low; medium; high), night shift work (yes; no), age at menarche (years), parity (yes; no), number of children, age at first birth (years), menopausal status (yes; no), HT use (never, ever), and OC use (never; ever). The follow-up started on the cohort baseline date (1st April 1993 or 1st April 1999) and ended at the date of breast cancer (event) or other cancer diagnoses (except non-melanoma skin cancer), death, emigration, or December 31, 2012 (censoring), whichever came first. We evaluated the effect of active smoking status, duration, intensity, and onset in separate models. We performed tests for trend by using the ordered category, including the reference as a continuous variable in the Cox model. We checked for the proportional hazards assumption for all smoking variables and confounders based on scaled Schoenfeld residuals. [22] The effect modification of an association 
between smoking and breast cancer by menopausal status, obesity, alcohol use, and HT use was evaluated by introducing interaction terms into the Cox model, and tested by the Wald test. Finally, separate models were fit for subtypes of breast cancer according to ER status (ER+; ER-) and ER status combined with PR status $(\mathrm{ER}+/ \mathrm{PR}+$; ER +/PR-; ER-/PR-; ER-/PR+) as outcomes. Results were presented as hazard ratios (HRs) and 95\% confidence intervals (CI). Analyses were performed in Stata 11.2.

The study was entirely based on a data from registers and approved by the Danish Data Inspection Agency, which by Danish law serving as ethical approval of register-based research. Thus, no contact has been taken with participating women, relatives or their practicing doctors, and no consent was needed.

\section{Results}

Of the total 28,731 nurses in the Danish Nurse Cohort, we excluded 4 due to inactive (emigrated) vital status and 1924 with cancer diagnosis before cohort baseline, and 4972 with missing information on one or more covariates. Of the 21,831 nurses in the main analyses 1162 developed breast cancer during the mean follow-up of 15.7 years or 342,538 person-years, with an incidence rate of 339 per 100,000 person-years.

The mean age at baseline was 53.2 years, $56.7 \%$ of the women were postmenopausal, $14.5 \%$ nulliparous, and the mean age at 1st childbirth for parous women was 25.9 years (Table 1). Compared with women who remained free of breast cancer, those who developed the cancer were more likely to be nulliparious, postmenopausal, obese, heavy alcohol drinkers, slightly physically active and HT users, but less likely to work night shifts, and use OC.

The majority of nurses (63.7\%) were ever smokers at cohort baseline, (33.7\% current, 30.0\% previous) whilst $36.3 \%$ never smokers. $38.3 \%$ of women who developed breast cancer were current smokers at baseline, as compared to $33.4 \%$ of women who were free of breast cancer (Table 1). Mean duration of smoking in ever smokers was 23.3 years, mean intensity $12.4 \mathrm{~g} /$ day or 16.0 packyears, and mean age at smoking initiation 20.4 years. Smoking duration and intensity were higher in nurses who developed breast cancer than in those who were free of breast cancer. $62.8 \%$ of parous women and $68.9 \%$ of nulliparous women were ever smokers. The majority of women started smoking early, before 1st childbirth or before age 21 (nulliparous women).

Whilst smoking rates and smoking intensity were lower in younger, as compared to older birth cohorts, the age at smoking initiation decreased, from 22.6 years in women born before 1935, to 17.8 in women born 1950-55 (Table 2). Accordingly, number of women smoking before 1st childbirth increased. Notably, also the use of HT and alcohol was higher in younger than in older birth cohorts.

Compared to never smokers, we found an increased risk of breast cancer in ever (HR: 1.18; 95\% CI: 1.04-1.34) smokers, strongest in current $(1.27 ; 1.11-1.46)$, and weaker in previous $(1.08$; 0.94-1.26) smokers (Table 3). We found a statistically significant dose-response association with increasing smoking duration and intensity, with highest risk of breast cancer observed in women smoking 21-20 years $(1.24 ; 1.06-1.46)$ and $>30$ years $(1.21 ; 1.01-1.46), 11-15 \mathrm{~g} /$ day $(1.22 ; 1.02-1.46)$ and $>15$ g/day $(1.31 ; 1.11-1.56)$, and $>20$ pack-years $(1.32 ; 1.12-1.55)$. Compared to parous never smokers, the risk of breast cancer seemed weaker in parous ever smokers who started smoking before (1.17; $1.02-1.34$, results not shown) than after $(1.28 ; 1.00-1.62)$ 1st childbirth. However, when accounting for smoking intensity, we found the strongest association among parous women who smoked heavily ( $>10$ pack-years) before 1st childbirth $(1.58 ; 1.20-2.10)$ and weak in those who smoked $\leq 10$ pack-years (1.13; 0.98-1.31). Nulliparous ever smokers had also increased risk of breast cancer, similar to that observed in parous women $(1.21 ; 0.88-1.67$, results not shown), and slightly higher with late ( $\geq$ age 21$)(1.29$; 0.89 $1.88)$ than with early $(<21$ years) $(1.10 ; 0.76-1.58)$ onset of smoking. When limiting analyses to the 12,376 women who were postmenopausal at the time of recruitment, we found that both women who started smoking before (1.20; $1.01-1.41)$ and after (1.66; 0.74-3.75) menopause had increased risk of breast cancer. Finally, when considering smoking intensity in different periods of life related to 1st childbirth and menopause among 8347 parous postmenopausal women, the strongest effect of smoking on breast cancer was observed with smoking before 1st childbirth (11-20 pack-years: $2.16 ; 1.45-3.20)$, and a weaker, but still strong effect was seen for smoking between 1st childbirth and menopause (> 20 pack-years: $1.84 ; 1.34-2.53$ ), while the weakest effects was seen for smoking after menopause (> 20 pack-years: 1.29 ; 0.70-4.98).

No statistically significant interaction was found between smoking and menopausal status at the time of recruitment, BMI, HT, or alcohol use (Table 4).

We found a slightly stronger association of smoking with ER+ $(1.17 ; 1.01-1.36)$ than with ER- $(1.11 ; 0.81-1.53)$ breast cancer, compared to never smoking (Table 5). When considering ER together with PR status, we found strongest associations of ever smoking with $\mathrm{ER}+/ \mathrm{PR}$ breast cancer $(1.75 ; 1.12-2.71)$, weaker with $E R+/ P R+$ breast cancer $(1.27 ; 1.02-1.59)$, and none with ER-/PR(1.08; $0.72-1.611)$ or ER-/PR- (1.02; 0.26-4.07) breast cancer (Table 5).

\section{Discussion}

In this Danish Nationwide cohort of female nurses we found a positive association between active tobacco 
Table 1 Description of the Danish Nurse Cohort $(n=21,831)$ at the time of recruitment in 1993 or 1999 and by breast cancer status during follow-up until 2013

\begin{tabular}{|c|c|c|c|}
\hline & $\begin{array}{l}\text { Total } \\
N=21,831\end{array}$ & $\begin{array}{l}\text { Breast Cancer } \\
N=1162\end{array}$ & $\begin{array}{l}\text { No Breast Cancer } \\
N=20,669\end{array}$ \\
\hline \multicolumn{4}{|l|}{ Age } \\
\hline Mean (SD) age at baseline (years) & $53.2(8.0)$ & $53.7(7.6)$ & $53.2(8.1)$ \\
\hline \multicolumn{4}{|l|}{ Birth Cohort } \\
\hline Born 1900-1934, n (\%) & $5179(23.7)$ & $295(25.4)$ & $4884(23.6)$ \\
\hline Born 1935-1944, n (\%) & $6707(30.7)$ & $428(36.8)$ & $6279(30.4)$ \\
\hline Born 1945-1949, n (\%) & $4564(20.9)$ & $244(21.0)$ & $4320(20.9)$ \\
\hline Born 1950-1955, n (\%) & $5381(24.6)$ & $195(16.8)$ & $5186(25.1)$ \\
\hline \multicolumn{4}{|l|}{ Reproductive Factors } \\
\hline Mean (SD) age at menarche & $13.5(1.5)$ & $13.5(1.5)$ & $13.5(1.5)$ \\
\hline Nulliparous, n (\%) & $3170(14.5)$ & $189(16.3)$ & $2981(14.4)$ \\
\hline Mean (SD) number of children in parous women & $2.3(0.9)$ & $2.3(0.9)$ & $2.3(0.9)$ \\
\hline Mean (SD) age at first birth in parous women & $25.9(4.0)$ & $25.9(4.0)$ & $26.3(4.1)$ \\
\hline Postmenopausal, n (\%) & $12,376(56.7)$ & $696(59.9)$ & $11,680(56.5)$ \\
\hline \multicolumn{4}{|l|}{ Body Mass Index (BMI) } \\
\hline Mean (SD) BMI $\left(\mathrm{kg} / \mathrm{m}^{2}\right)$ & $23.7(3.5)$ & $23.8(3.5)$ & $23.7(3.5)$ \\
\hline $\mathrm{BMI}<18.5 \mathrm{~kg} / \mathrm{m}^{2}, \mathrm{n}(\%)$ & $529(2.4)$ & $22(1.9)$ & $507(2.5)$ \\
\hline BMI $18.5-24.9$ kg/m², n (\%) & $15,070(69.0)$ & $819(70.5)$ & $14,251(68.9)$ \\
\hline BMI $25-29.9$ kg/m², n (\%) & $4979(22.8)$ & $245(21.1)$ & $4734(22.9)$ \\
\hline $\mathrm{BMI} \geq 30 \mathrm{~kg} / \mathrm{m}^{2}, \mathrm{n}(\%)$ & $1253(5.7)$ & $76(6.5)$ & $1177(5.7)$ \\
\hline \multicolumn{4}{|l|}{ Alcohol consumption } \\
\hline Does not drink alcohol, n (\%) & $3320(15.2)$ & $183(15.7)$ & $3137(15.2)$ \\
\hline Moderate drinker (1-14 drinks/week), n (\%) & $13,533(62.0)$ & $670(57.7)$ & $12,863(62.2)$ \\
\hline Heavy drinker (> 14 drinks/week), n (\%) & $4978(22.8)$ & $309(26.6)$ & 4669 (22.6) \\
\hline \multicolumn{4}{|l|}{ Leisure time physical activity } \\
\hline Low physical activity, n (\%) & $1428(6.5)$ & $79(6.8)$ & $1349(6.5)$ \\
\hline Medium physical activity, n (\%) & $5905(27.0)$ & $298(25.6)$ & $5607(27.1)$ \\
\hline High physical activity, n (\%) & $14,498(66.4)$ & $785(67.6)$ & $13,713(66.3)$ \\
\hline \multicolumn{4}{|l|}{ Shift Work } \\
\hline Working night shifts, n (\%) & $967(5.5)$ & $45(4.9)$ & $922(5.5)$ \\
\hline \multicolumn{4}{|l|}{ Hormone Use } \\
\hline Ever used oral contraceptives, n (\%) & $12,701(58.2)$ & $663(57.1)$ & $12,038(58.2)$ \\
\hline Ever used hormone therapy, n (\%) & $5951(27.3)$ & $407(35.0)$ & $5544(26.8)$ \\
\hline \multicolumn{4}{|l|}{ Smoking Status } \\
\hline Never smoker, n (\%) & $7923(36.3)$ & $379(32.6)$ & $7544(36.5)$ \\
\hline Former smoker, n (\%) & $6557(30.0)$ & $338(29.1)$ & $6219(30.1)$ \\
\hline Current smoker, n (\%) & $7351(33.7)$ & $445(38.3)$ & $6906(33.4)$ \\
\hline Ever smoker, n (\%) & $13,908(63.7)$ & $783(67.4)$ & $13,125(63.5)$ \\
\hline \multicolumn{4}{|l|}{ Smoking Intensity } \\
\hline Mean (SD) smoking duration ${ }^{a}$ (years) & $23.3(12.2)$ & $23.9(11.7)$ & $23.3(12.2)$ \\
\hline Mean (SD) smoking intensity ${ }^{a}$ (g/day) & $12.4(8.3)$ & $12.7(8.0)$ & $12.4(8.3)$ \\
\hline Mean (SD) pack-years ${ }^{a}$ & $16.0(14.8)$ & $16.6(14.8)$ & $15.9(14.8)$ \\
\hline \multicolumn{4}{|l|}{ Initiation of smoking } \\
\hline Mean age (SD) at smoking initiation ${ }^{a}$ (years) & $20.4(5.5)$ & $20.7(5.7)$ & $20.4(5.5)$ \\
\hline
\end{tabular}


Table 1 Description of the Danish Nurse Cohort $(n=21,831)$ at the time of recruitment in 1993 or 1999 and by breast cancer status during follow-up until 2013 (Continued)

\begin{tabular}{|c|c|c|c|}
\hline \multicolumn{4}{|l|}{ Initiation of smoking in 18,661 parous women } \\
\hline Parous never smoker & $6938(37.2)$ & $326(33.5)$ & $6612(37.4)$ \\
\hline Parous ever smoker & $11,723(62.8)$ & $647(66.5)$ & $11,076(62.6)$ \\
\hline Parous/around 1st birth or later, n (\%) & $1457(6.7)$ & $88(7.6)$ & $1369(6.6)$ \\
\hline Parous/before 1st childbirth, $\leq 10$ pack-years, $\mathrm{n}(\%)$ & $9367(42.9)$ & $493(42.4)$ & $8874(42.9)$ \\
\hline Parous/before 1st childbirth, > 10 pack-years, n (\%) & $899(4.1)$ & $66(5.7)$ & $833(4.0)$ \\
\hline \multicolumn{4}{|l|}{ Initiation of smoking in 3170 nulliparous women } \\
\hline Nulliparous never smoker & $985(31.1)$ & $53(28.0)$ & $932(31.3)$ \\
\hline Nulliparous ever smoker & $2185(68.9)$ & $136(72.0)$ & $2049(68.7)$ \\
\hline Nulliparous, before age $21^{\mathrm{b}}$ years, $\mathrm{n}(\%)$ & $1264(5.8)$ & $74(6.4)$ & $1190(5.8)$ \\
\hline Nulliparous, age 21 years or later, n (\%) & $921(4.2)$ & $62(5.3)$ & $859(4.2)$ \\
\hline \multicolumn{4}{|l|}{ Initiation of smoking in 12,376 postmenopausal women } \\
\hline Postmenopausal never smoker, n (\%) & $3988(32.2)$ & $202(29.0)$ & $3786(32.4)$ \\
\hline Before menopause, n (\%) & $8301(67.1)$ & $488(70.1)$ & $7813(66.9)$ \\
\hline After menopause, n (\%) & $87(0.7)$ & $6(0.9)$ & $81(0.7)$ \\
\hline
\end{tabular}

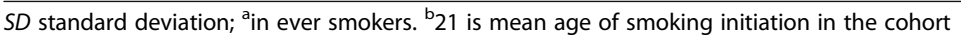

smoking and breast cancer incidence in women older than 44 years, with the highest risk in women who smoked heavily and for a long duration of time. The strongest risk was detected in parous women who smoked heavily before 1 st childbirth.

Our results confirmed the association between active smoking and breast cancer incidence reported in almost all recent prospective cohort studies. [6-13] Albeit, the $27 \%$ increased breast cancer risk that we found in current as compared to never smokers, was stronger than the effects seen in any of the earlier prospective studies. In other previous studies the risk of breast cancer was reported to be increased by $24 \%$ in both the American Cancer Society's Cancer Prevention Study II (CPS-II) [10] and the Women's Health Initiative (WHI) [7] studies; by $19 \%$ in the Norwegian women [9]; by $15 \%$ in American retired women [13]; by $8 \%$ in American Black Women's Health Study (BWHS) [8]; by $5 \%$ in American Nurses' Health Study (NHS) [6]; and by 6\% in the EPIC cohort. [11] We also found a strong effect of high smoking intensity, with a $32 \%$ increased risk of breast cancer risk in women smoking $>20$ pack-years; a risk comparable to $34 \%$ increased risk observed in Norwegian women smoking $\geq 16$ pack-years, [9] but stronger than effects found in any other study. $[6-8,11,13]$

The strong effects of smoking observed in both, our and in the Norwegian cohorts (both that part of EPIC study [11] and the other Norwegian cohorts [9]) may be explained by high prevalence, duration and intensity of smoking in these Nordic cohorts with $34 \%$ of the women being current smokers at the time of recruitment as compared with $13 \%$ in American nurses, [6] 8\% in the American CPS-II study, [10] and $6 \%$ in the WHI study. [7] The average number of current smokers at the time of recruitment for the European countries in the EPIC study was 20\%. [11] Furthermore, as we did not have data on passive smoking, our estimates for smoking are likely underestimated, as the EPIC study found that excluding passive smokers from the reference group led to higher risk estimates for active smoking. [11]

Notably, no association between smoking and breast cancer was found (current vs. never: 1.05; 0.72-1.54; former vs. never: $1.00 ; 0.68-1.47)$ in the Danish Diet, Cancer and Health cohort, which formed the Danish part of the EPIC study. [11] A possible reason for the difference between our results and those from Danish EPIC cohort could be that the women in the cohorts came from different birth cohorts. In the Danish EPIC cohort, the majority of women were born before 1944, and only 10\% were born in 1945-1950. In the Danish Nurse Cohort, half of the women were born in 19451955 (Table 2). These younger birth cohorts started smoking earlier and were able to accumulate more years of smoking before the 1st childbirth than the older birth cohorts: on average 7.8 years as compared to 5.3 years (Table 2). The oldest generations in the Danish Nurse Cohort furthermore included a high proportion of nulliparous women; 27\% for nurses born in 1990-1934 (Table 2), reflecting that before the Second World War Danish nurses were mostly unmarried. Finally, the EPIC cohort might be affected by a "healthy worker effect", as the cohort members were recruited from general 
Table 2 Description of the Danish Nurse Cohort $(n=21,831)$ at the time of recruitment in 1993 or 1993 and by birth cohort

\begin{tabular}{|c|c|c|c|c|}
\hline Birth Cohort & $\begin{array}{l}1900-1934 \\
N=5179\end{array}$ & $\begin{array}{l}1935-1944 \\
N=6707\end{array}$ & $\begin{array}{l}1945-1949 \\
N=4564\end{array}$ & $\begin{array}{l}1950-1955 \\
N=5381\end{array}$ \\
\hline \multicolumn{5}{|l|}{ Age } \\
\hline Mean (SD) age at baseline (years) & $65.3(5.8)$ & $53.1(3.0)$ & $47.7(1.9)$ & $46.4(1.5)$ \\
\hline \multicolumn{5}{|l|}{ Reproductive Factors } \\
\hline Mean (SD) age at menarche & $14.0(1.5)$ & $13.6(1.6)$ & $13.4(1.5)$ & $13.2(1.5)$ \\
\hline Nulliparous, n (\%) & $1401(27.1)$ & $764(11.4)$ & $431(9.4)$ & $574(10.7)$ \\
\hline Mean (SD) number of children in parous women & $2.5(1.0)$ & $2.4(0.9)$ & $2.3(0.8)$ & $2.3(0.8)$ \\
\hline Mean (SD) age at first birth in parous women & $27.9(4.1)$ & $25.7(3.6)$ & $25.0(3.6)$ & $25.6(4.2)$ \\
\hline Postmenopausal, n (\%) & $5170(99.8)$ & $5060(75.4)$ & $1240(27.2)$ & $906(16.8)$ \\
\hline \multicolumn{5}{|l|}{ Body Mass Index (BMI) } \\
\hline Mean (SD) BMI $\left(\mathrm{kg} / \mathrm{m}^{2}\right)$ & $23.8(3.5)$ & $23.7(3.4)$ & $23.5(3.4)$ & $23.8(3.6)$ \\
\hline $\mathrm{BMI}<18.5 \mathrm{~kg} / \mathrm{m}^{2}, \mathrm{n}(\%)$ & $199(3.8)$ & $148(2.2)$ & $100(2.2)$ & $82(1.5)$ \\
\hline BMI $18.5-24.9 \mathrm{~kg} / \mathrm{m}^{2}, \mathrm{n}(\%)$ & $3368(65.0)$ & $4657(69.4)$ & $3293(72.2)$ & $3752(69.7)$ \\
\hline BMI $25-29.9$ kg/m², n (\%) & $1315(25.4)$ & $1527(22.8)$ & $944(20.7)$ & $1193(22.2)$ \\
\hline $\mathrm{BMI} \geq 30 \mathrm{~kg} / \mathrm{m}^{2}, \mathrm{n}(\%)$ & $297(5.7)$ & $375(5.6)$ & $227(5.0)$ & $354(6.6)$ \\
\hline \multicolumn{5}{|l|}{ Alcohol consumption } \\
\hline Does not drink alcohol, n (\%) & $1278(24.7)$ & $980(14.6)$ & $516(11.3)$ & $546(10.1)$ \\
\hline Moderate drinker (1-14 drinks/week), n (\%) & $2900(56.0)$ & $4177(62.3)$ & $2923(64.0)$ & $3533(65.7)$ \\
\hline Heavy drinker (> 14 drinks/week), n (\%) & $1001(19.3)$ & $1550(23.1)$ & $1125(24.6)$ & $1302(24.2)$ \\
\hline \multicolumn{5}{|l|}{ Leisure time physical activity } \\
\hline Low physical activity, n (\%) & $467(9.0)$ & $392(5.8)$ & $250(5.5)$ & $319(5.9)$ \\
\hline Medium physical activity, n (\%) & $1090(21.0)$ & $1809(27.0)$ & $1406(30.8)$ & $1600(29.7)$ \\
\hline High physical activity, n (\%) & $3622(69.9)$ & $4506(67.2)$ & $2908(63.7)$ & $3462(64.3)$ \\
\hline \multicolumn{5}{|l|}{ Shift Work } \\
\hline Working night shifts, n (\%) & $191(12.5)$ & $453(7.4)$ & $178(4.0)$ & $145(2.7)$ \\
\hline \multicolumn{5}{|l|}{ Hormone Use } \\
\hline Ever used oral contraceptives, n (\%) & $2082(40.2)$ & $2490(37.1)$ & $779(17.1)$ & $600(11.2)$ \\
\hline Ever used hormone therapy, n (\%) & $1143(22.1)$ & $3544(52.8)$ & $3462(75.9)$ & $4552(84.6)$ \\
\hline \multicolumn{5}{|l|}{ Smoking status } \\
\hline Never smoker, n (\%) & $1481(28.6)$ & $2487(37.1)$ & $1840(40.3)$ & $2115(39.3)$ \\
\hline Former smoker, n (\%) & $1812(35.0)$ & $1716(25.6)$ & $1242(27.2)$ & $1787(33.2)$ \\
\hline Current smoker, n (\%) & $1886(36.4)$ & $2504(37.3)$ & $1482(32.5)$ & $1479(27.5)$ \\
\hline Ever smoker, n (\%) & $3698(71.4)$ & $4220(62.9)$ & $2724(59.7)$ & $3266(60.7)$ \\
\hline \multicolumn{5}{|l|}{ Smoking Intensity } \\
\hline Mean (SD) smoking duration ${ }^{a}$ (years) & $29.4(14.5)$ & $23.4(11.3)$ & $19.8(9.5)$ & $19.4(9.2)$ \\
\hline Mean (SD) smoking intensity ${ }^{a}(\mathrm{~g} /$ day) & $12.1(9.0)$ & $13.0(8.8)$ & $12.5(7.5)$ & $12.0(7.5)$ \\
\hline Mean (SD) pack-years ${ }^{\mathrm{a}}$ & $19.5(18.6)$ & $16.9(14.9)$ & $13.5(11.1)$ & $12.8(11.0)$ \\
\hline \multicolumn{5}{|l|}{ Initiation of smoking } \\
\hline Mean age (SD) at smoking initiation ${ }^{a}$ (years) & $22.6(6.9)$ & $21.1(5.3)$ & $19.6(3.9)$ & $17.8(3.3)$ \\
\hline \multicolumn{5}{|l|}{ Initiation of smoking in 18,661 parous women } \\
\hline Parous never smoker, n (\%) & $1078(28.5)$ & $2246(37.8)$ & $1684(40.8)$ & $1930(40.2)$ \\
\hline Parous ever smoker, n (\%) & $2700(71.5)$ & $3697(62.2)$ & $2449(59.3)$ & $2877(59.9)$ \\
\hline Parous/around 1st birth or later, n (\%) & $430(8.3)$ & $632(9.4)$ & $259(5.7)$ & $136(2.5)$ \\
\hline Parous/before 1st childbirth, $\leq 10$ pack-years, n (\%) & $2047(39.5)$ & $2824(42.1)$ & $2037(44.6)$ & $2459(45.7)$ \\
\hline
\end{tabular}


Table 2 Description of the Danish Nurse Cohort $(n=21,831)$ at the time of recruitment in 1993 or 1993 and by birth cohort (Continued)

\begin{tabular}{|c|c|c|c|c|}
\hline Parous/before 1st childbirth, > 10 pack-years, n (\%) & $223(4.3)$ & $241(3.6)$ & $153(3.4)$ & $282(5.2)$ \\
\hline \multicolumn{5}{|l|}{ Initiation of smoking in 3170 nulliparous women } \\
\hline Nulliparous never smoker, n (\%) & $403(28.8)$ & $241(31.5)$ & $156(36.2)$ & $185(32.2)$ \\
\hline Nulliparous ever smoker, n (\%) & $998(71.2)$ & $523(68.5)$ & $275(63.8)$ & $389(67.8)$ \\
\hline Nulliparous, before age $21^{\mathrm{b}}$ years, $\mathrm{n}(\%)$ & $442(8.5)$ & $295(4.4)$ & $187(4.1)$ & $340(6.3)$ \\
\hline Nulliparous, age 21 years or later, n (\%) & $556(10.7)$ & $228(3.4)$ & $88(1.9)$ & $49(0.9)$ \\
\hline \multicolumn{5}{|l|}{ Initiation of smoking in 12,376 postmenopausal women } \\
\hline Postmenopausal never smoker, n (\%) & $1477(28.6)$ & $1757(34.7)$ & $454(36.6)$ & $300(33.1)$ \\
\hline Postmenopausal ever smoker, n (\%) & $3693(71.4)$ & $3303(65.3)$ & $786(63.4)$ & $606(66.9)$ \\
\hline Before menopause, n (\%) & $3633(70.3)$ & $3281(64.8)$ & $782(63.1)$ & $605(66.8)$ \\
\hline After menopause, n (\%) & $60(1.2)$ & $22(0.4)$ & $4(0.3)$ & $1(0.1)$ \\
\hline
\end{tabular}

SD standard deviation; ${ }^{a}$ in ever smokers. ${ }^{\mathrm{b}} 21$ is mean age of smoking initiation in the cohort

population and only 37\% participated [23] as compared to $86 \%$ participation rate in the Danish Nurse Cohort. [18] While the percentage of never smokers was 36\% in the Danish Nurse Cohort, it was $43 \%$ in the Danish EPIC cohort. [11]

We found the highest risk of breast cancer related to smoking heavily before the 1st childbirth, in agreement with existing evidence. [6-8, 10-12] Breast development with increased epithelial cell proliferation begins before the menarche, [24] while the terminal differentiation of the breast epithelium takes place in the last trimester of pregnancy. [25] It is therefore plausible that the time before the 1st pregnancy may be critical for susceptibility to tobacco smoke carcinogens. In contrast to the EPIC study, [11] no protective effect of smoking in postmenopausal age was found in either American [6] or Danish nurses.

As alcohol is an established risk factor for breast cancer, and as alcohol and smoking often come together, the possible confounding by alcohol of the effect of smoking on the risk of breast cancer has been debated in literature. Alcohol has also been previously shown to be an independent risk factor for breast cancer in the Danish Nurse Cohort. [26] However, alcohol did not seem to be a confounder in our study. Our risk estimates were adjusted for intensity of alcohol consumption. The breast cancer risk was somewhat enhanced in heavy drinking current smokers, but, in line with the results of the EPIC study, [11] the trend of increase in risk of smoking by increasing level of alcohol consumption was not statistically significant neither for ever nor for current smokers (Table 4). The available data thus indicate that the effect of smoking on breast cancer risk is independent of the effect of alcohol.

We contribute with novel data on smoking and subtypes of breast cancer, as only a few studies have previously included this information. $[7,10,11,13]$ We detected a very strong association between current (vs. never) smoking and ER+/PR- breast cancer (1.92; 1.19-3.10), followed by a weaker but robust association with $\mathrm{ER}+/ \mathrm{PR}+$ breast cancer $(1.36 ; 1.06-1.76)$, and none for ER-/PR- or ER-/PR+ breast cancers. This is in agreement with EPIC study, which reported the strongest risk related to current smoking of $34 \%$ for ER+/PR-, $23 \%$ for ER+/PR+, and 13\% for ER-/PR-, [11] and American Retired women study which found $37 \%$ increased risk of $E R+/ P R-$ breast cancer in current smokers, and none with ER+/PR+ or ER-/PRsubtypes. [13] Luo et al. has reported a $28 \%$ increased risk of $\mathrm{ER}+/ \mathrm{PR}+$ breast cancer in current compared to never smoker, but in contrast to our study and current literature, none with ER+/PR- or ER-/PR-, [7] whereas Gaudet et al. reported association with smoking limited to ER+ breast cancer subtype, and none with ER-, but lacked data on PR status. [10]

Strengths of this study include data from a large prospective nationwide cohort with comprehensive followup of both vital status and incident breast cancer cases from linkage with nationwide registers. Exposure information from the cohort was expected to be valid as already known associations between breast cancer and, for instance, alcohol use [26] and HT [26-28] have already been documented in this cohort. Another strength was the high smoking prevalence, where $34 \%$ of women in our cohort were current smokers. This means that potential confounding not controlled for will affect our results less than is the case in the studies where smokers constitute a smaller, and thus a more marginalized group of women.

The main limitation was the exposure misclassification as the smoking exposure was based on questionnaires at the time of recruitment, without follow-up, and the lack of information on passive tobacco smoke. However, prevalence of active and passive smoking in Denmark in this period was high, and based on data from a related 
Table 3 Association between active smoking and breast cancer in 21,831 women in the Danish Nurse Cohort

\begin{tabular}{|c|c|c|c|c|c|}
\hline & N & $\begin{array}{l}\text { Person- } \\
\text { years }\end{array}$ & $\begin{array}{l}\text { No. } \\
\text { of } \\
\text { cases }\end{array}$ & $\begin{array}{l}\text { Age adjusted } \\
\text { HR (95\% Cl) }\end{array}$ & $\begin{array}{l}\text { Fully a adjusted } \\
\text { HR }(95 \% \text { Cl) }\end{array}$ \\
\hline Never smoked (ref.) & 7923 & 126,950 & 379 & 1.00 & 1.00 \\
\hline Former smoker & 6557 & 102,190 & 338 & $1.11(0.96-1.29)$ & $1.08(0.94-1.26)$ \\
\hline Current smoker & 7351 & 113,400 & 445 & $1.32(1.15-1.51)$ & $1.27(1.11-1.46)$ \\
\hline Ever smokers & 13,908 & 215,589 & 783 & $1.22(1.08-1.38)$ & $1.18(1.04-1.34)$ \\
\hline \multicolumn{6}{|l|}{ Smoking duration among ever smokers } \\
\hline$\leq 10$ years & 2925 & 47,335 & 156 & $1.10(0.92-1.33)$ & $1.10(0.91-1.33)$ \\
\hline $11-20$ years & 3175 & 50,151 & 175 & $1.17(0.98-1,40)$ & $1.15(0.96-1.38)$ \\
\hline $21-30$ years & 4456 & 68,818 & 259 & $1.26(1.08-1.48)$ & $1.24(1.06-1.46)$ \\
\hline$>30$ years & 3295 & 49,285 & 193 & $1.32(1.11-1.57)$ & $1.21(1.01-1.46)$ \\
\hline$p$-value for trend & & & & & 0.004 \\
\hline Every increase of 10 years & & & & $1.08(1.04-1.12)$ & $1.06(1.02-1-11)$ \\
\hline \multicolumn{6}{|l|}{ Smoking (Tobacco) Intensity among ever smokers } \\
\hline$>6$ g/day & 3098 & 49,245 & 161 & $1.10(0.91-1.32)$ & $1.07(0.89-1.29)$ \\
\hline 6-10 g/day & 4317 & 67,410 & 235 & $1.17(0.99-1.38)$ & $1.14(0.97-1.34)$ \\
\hline $11-15 \mathrm{~g} /$ day & 3050 & 46,962 & 175 & $1.25(1.05-1.50)$ & $1.22(1.02-1.46)$ \\
\hline$>15 \mathrm{~g} /$ day & 3443 & 51,973 & 212 & $1.37(1.16-1.62)$ & $1.31(1.11-1.56)$ \\
\hline$p$-value for trend & & & & & 0.001 \\
\hline Every increase of $10 \mathrm{~g} /$ day & & & & $1.05(0.97-1.14)$ & $1.04(0.95-1.13)$ \\
\hline \multicolumn{6}{|l|}{ Lifetime pack-years } \\
\hline$\leq 10$ pack-years & 6082 & 96,640 & 327 & $1.13(0.98-1.31)$ & $1.12(0.97-1.30)$ \\
\hline 11-20 pack-years & 3536 & 54,993 & 192 & $1.17(0.99-1.39)$ & $1.14(0.96-1.36)$ \\
\hline$>20$ pack-years & 4290 & 63,956 & 264 & $1.39(1.19-1.63)$ & $1.32(1.12-1.55)$ \\
\hline$p$-value for trend & & & & & 0.002 \\
\hline Every increase of 20 pack-years & & & & $1.10(1.01-1.20)$ & $1.07(0.98-1.18)$ \\
\hline \multicolumn{6}{|l|}{ Initiation of smoking in 18,661 parous women } \\
\hline Parous never smoker (ref.) & 6938 & 111,811 & 326 & 1.00 & 1.00 \\
\hline Parous, around first birth or later & 1457 & 23,553 & 88 & $1.28(1.01-1.62)$ & $1.28(1.00-1.62)$ \\
\hline Parous, before first childbirth, $\leq 10$ pack-years & 9367 & 146,965 & 493 & $1.15(1.00-1.33)$ & $1.13(0.98-1.31)$ \\
\hline Parous, before first childbirth, $>10$ pack-years & 899 & 12,901 & 66 & $1.77(1.36-2-31)$ & $1.58(1.20-2.10)$ \\
\hline \multicolumn{6}{|l|}{ Initiation of smoking in 3170 nulliparous women } \\
\hline Nulliparous never smoker (ref.) & 985 & 15,138 & 53 & 1.00 & 1.00 \\
\hline Nulliparous, before age $21^{\mathrm{b}}$ years & 1264 & 18,737 & 74 & $1.14(0.80-1.62)$ & $1.10(0.76-1.58)$ \\
\hline Nulliparous, age 21 years or later & 921 & 13,434 & 62 & $1.31(0.91-1.90)$ & $1.29(0.89-1.88)$ \\
\hline \multicolumn{6}{|c|}{ Initiation of smoking in 12,376 postmenopausal women } \\
\hline Postmenopausal never smoker (ref.) & 3988 & 66,617 & 202 & 1.00 & 1.00 \\
\hline Before menopause & 8301 & 130,987 & 488 & $1.23(1.05-1.45)$ & $1.20(1.01-1.41)$ \\
\hline After menopause & 87 & 1252 & 6 & $1.60(0.71-3.59)$ & $1.66(0.74-3.75)$ \\
\hline \multicolumn{6}{|l|}{ Pack-years in 8347 parous postmenopausal women ${ }^{c}$} \\
\hline Parous postmenopausal never smoker (ref.) & 2712 & & 129 & 1.00 & 1.00 \\
\hline \multicolumn{6}{|l|}{ Pack-years before 1st childbirth ${ }^{d}$} \\
\hline$\leq 10$ pack-years & 4349 & 70,627 & 227 & $1.16(0.93-1.44)$ & $1.14(0.92-1.42)$ \\
\hline 11-20 pack-years & 366 & 5233 & 34 & $2.36(1.62-3.45)$ & $2.16(1.45-3.20)$ \\
\hline > 20 pack-years & 61 & 854 & 4 & $1.69(0.63-4.59)$ & $1.38(0.50-3.78)$ \\
\hline
\end{tabular}


Table 3 Association between active smoking and breast cancer in 21,831 women in the Danish Nurse Cohort (Continued)

\begin{tabular}{|c|c|c|c|c|c|}
\hline$p$-value for trend & & & & & 0.006 \\
\hline \multicolumn{6}{|c|}{ Pack-years from 1st childbirth until menopause ${ }^{d}$} \\
\hline$\leq 10$ pack-years & 2572 & 42,484 & 128 & $1.08(0.85-1.38)$ & $1.03(0.81-1.33)$ \\
\hline 11-20 pack-years & 1606 & 25,391 & 79 & $1.12(0.85-1.49)$ & $1.13(0.85-1.50)$ \\
\hline > 20 pack-years & 817 & 12,471 & 60 & $1.74(1.28-2.36)$ & $1.84(1.34-2.53)$ \\
\hline$p$-value for trend & & & & & 0.029 \\
\hline \multicolumn{6}{|c|}{ Pack-years after menopause ${ }^{d}$} \\
\hline$\leq 10$ pack-years & 2294 & 37,270 & 124 & $1.20(0.94-1.53)$ & $1.19(0.93-1.53)$ \\
\hline 11-20 pack-years & 453 & 6695 & 20 & $1.09(0.68-1.74)$ & $1.03(0.64-1.66)$ \\
\hline$>20$ pack-years & 1966 & 32,094 & 118 & $1.32(1.03-1.70)$ & $1.29(0.70-4.98)$ \\
\hline$p$-value for trend & & & & & 0.412 \\
\hline
\end{tabular}

HR hazard ratio, $\mathrm{Cl}$ confidence interval ${ }^{\mathrm{a}}$ Adjusted for age, no of births, Body Mass Index, physical activity, alcohol use, oral contraceptive use, age at menarche, menopause, age at 1st birth, parity, number of birth, hormone therapy use, and night shift work. ${ }^{b} 21$ is mean age at 1 st childbirth in this cohort; ${ }^{c}$ with information on age at cessation of menstrual bleeding; ${ }^{d}$ every increase of 20 pack-years

Danish Diet, Cancer and Health cohort recruited in the same period, we estimated earlier that only $5 \%$ of women in this period were not exposed to passive smoke at home or work. [29] In any case, passive smoking is difficult to assess accurately, due to its ubiquitous exposure, and the American nurses study failed to find an association between passive smoking and breast cancer, [6] while the EPIC study found that excluding passive smokers from the reference group led to higher risk estimates for active smoking. [11]
Danish nurses have been found to live a generally healthier lifestyle than a representative sample of Danish women, as they smoked less and had higher physical activity levels, although they consumed more alcohol. [18] Furthermore, there was no major differences between Danish nurses and Danish women in general with respect to use of health care and disease occurrence. [18] It is therefore reasonable to generalize the findings based on the Danish Nurses Cohort to Danish women in general.

Table 4 Effect modification of association between active smoking and breast cancer in 21,831 women in the Danish Nurse Cohort by menopausal status, obesity, alcohol consumption and hormone therapy use

\begin{tabular}{|c|c|c|c|c|c|c|}
\hline & & & Never & Former & Current & Ever \\
\hline & $N$ & No. of cases & $\mathrm{HR}(95 \% \mathrm{Cl})$ & $\mathrm{HR}(95 \% \mathrm{Cl})$ & $\mathrm{HR}(95 \% \mathrm{Cl})$ & $\mathrm{HR}(95 \% \mathrm{Cl})$ \\
\hline \multicolumn{7}{|l|}{ Menopausal status } \\
\hline Premenopausal & 9455 & 466 & 1.00 & $1.03(0.82-1.29)$ & $1.30(1.04-1.61)$ & $1.16(0.95-1.40)$ \\
\hline Postmenopausal & 12,376 & 696 & 1.00 & $1.12(1.92-1.37)$ & $1.27(1.05-1.52)$ & $1.20(1.02-1.42)$ \\
\hline$p$-value & & & & & 0.77 & 0.80 \\
\hline \multicolumn{7}{|l|}{ BMI } \\
\hline Not obese $\left(<30 \mathrm{~kg} / \mathrm{m}^{2}\right)$ & 20,578 & 1086 & 1.00 & $1.07(0.92-1.25)$ & $1.25(1.08-1.45)$ & $1.11(1.03-1.33)$ \\
\hline Obese $\left(\geq 30 \mathrm{~kg} / \mathrm{m}^{2}\right)$ & 1253 & 76 & 1.00 & $1.23(0.72-2.09)$ & $1.47(0.81-2.66)$ & $1.32(0.82-2.12)$ \\
\hline$p$-value & & & & & 0.84 & 0.63 \\
\hline \multicolumn{7}{|l|}{ Alcohol Consumption } \\
\hline None & 3320 & 183 & 1.00 & $1.11(0.77-1.61)$ & $1.17(0.83-1.66)$ & $1.14(0.85-1.54)$ \\
\hline Moderate (1-14 drinks/week) & 13,533 & 670 & 1.00 & $1.13(0.94-1.37)$ & $1.26(1.05-1.52)$ & $1.19(1.02-1.40)$ \\
\hline Heavy (>14 drinks/week) & 4978 & 309 & 1.00 & $0.96(0.70-1.31)$ & $1.34(1.01-1.77)$ & $1.17(0.90-1.52)$ \\
\hline$p$-value & & & & & 0.66 & 0.99 \\
\hline \multicolumn{7}{|l|}{ Hormone therapy use } \\
\hline Never & 15,880 & 755 & 1.00 & $1.05(0.88-1.26)$ & $1.21(1.02-1.44)$ & $1.13(0.97-1.32)$ \\
\hline Ever & 5951 & 407 & 1.00 & $1.15(0.88-1.49)$ & $1.36(1.06-1.73)$ & $126(1.01-1.58)$ \\
\hline$p$-value & & & & & 0.63 & 033 \\
\hline
\end{tabular}


Table 5 Association between ever vs. never smoking and breast cancer subtypes in 21,831 women from Danish Nurse Cohort

\begin{tabular}{|c|c|c|c|c|c|}
\hline & & Never & Former & Current & Ever \\
\hline & $N$ & Ref. & $\mathrm{HR}(95 \% \mathrm{Cl})$ & HR $(95 \% \mathrm{Cl})$ & $\mathrm{HR}(95 \% \mathrm{Cl})$ \\
\hline \multicolumn{6}{|c|}{ Estrogen Receptor (ER) Status } \\
\hline $\mathrm{ER}+$ & 851 & 1.00 & $1.06(0.89-1.26)$ & $1.28(1.09-1.51)$ & $1.17(1.01-1.36)$ \\
\hline ER - & 172 & 1.00 & $1.11(0.77-1.62)$ & $1.11(0.77-1.61)$ & $1.11(0.81-1.53)$ \\
\hline \multicolumn{6}{|c|}{ Receptor Status } \\
\hline $\mathrm{ER}+/ \mathrm{PR}+$ & 366 & 1.00 & $1.17(0.90-1.53)$ & $1.36(1.06-1.76)$ & $1.27(1.02-1.59)$ \\
\hline $\mathrm{ER}+/ \mathrm{PR}-$ & 111 & 1.00 & $1.56(0.94-2.59)$ & $1.92(1.19-3.10)$ & $1.75(1.12-2.71)$ \\
\hline ER-/PR- & 107 & 1.00 & $1.01(0.63-1.63)$ & $1.15(0.73-1.82)$ & $1.08(0.72-1.61)$ \\
\hline ER-/PR+ & 10 & 1.00 & $1.76(0.41-7.56)$ & $0.49(0.08-3.01)$ & $1.02(0.26-4.07)$ \\
\hline
\end{tabular}

\section{Conclusion}

In this cohort of Danish nurses, we found the risk of breast cancer to be almost $30 \%$ increased in current smokers as compared with never smokers. The risk increases both with smoking duration and smoking intensity. The highest risk was seen in women with more than 10 pack-years of smoking before the birth of their first child. We found no protective effect of smoking in post-menopausal age. The study contributed to the accumulating evidence for smoking - in particular in early life - as causally associated with an increased risk of breast cancer.

\section{Abbreviations}

BMI: Body Mass Index; BWHS: Black Women's Health Study; Cl: Confidence Intervals; CPS-II: Cancer Prevention Study II; EPIC: European Prospective investigation into Cancer and Nutrition; ER: Estrogen Receptor; HR: Hazard Ratio; HT: Hormone Therapy; IARC: International Agency for Research on Cancer; OC: Oral Contraceptives; PR: Progesterone Receptor; WHI: Women's Health Initiative

\section{Acknowledgements}

None.

\section{Funding}

This work was supported by the Novo Nordisk Foundation [NNF6935].

\section{Availability of data and materials}

The dataset supporting the conclusions of this article will be archived in the Danish Data Archive (https://www.sa.dk/en/about-us/danish-national-archives).

\section{Authors' contributions}

All authors made substantial contributions to conception and design, analysis, and interpretation of data, and critical review of the manuscript. ZJA contributed with an idea and design for the study, secured funding, and drafted the manuscript. JTJ performed the statistical analyses and contributed revising of the manuscript. EL helped with the design of the study and was involved in drafting the manuscript with respect to the literature review and interpretation of the results. EVB and RG have been involved in revising the manuscript critically for important intellectual content. All authors read and approved the final manuscript.

\section{Ethics approval and consent to participate}

The study was entirely based on register data and was approved by the Danish Data Protection Agency (2014-41-2750). Danish law regarding ethical approval of register-based research does not require informed consent from study participants, thus no contact was made with the participating women or their relatives and general practitioners.

\section{Consent for publication}

Danish law regarding ethical approval of register-based research does not require consent from study participants to publish.

\section{Competing interests}

The authors declare that they have no competing interests.

\section{Publisher's Note}

Springer Nature remains neutral with regard to jurisdictional claims in published maps and institutional affiliations.

\section{Author details \\ ${ }^{1}$ Centre for Epidemiology and Screening, Department of Public Health, University of Copenhagen, Øster Farimagsgade 5, 1014 Copenhagen, Denmark. ${ }^{2}$ Department of Occupational and Environmental Medicine, Bispebjerg - Frederiksberg Hospital, University of Copenhagen, Bispebjerg Bakke 23, Building 20C, 2400 Copenhagen, Denmark. ${ }^{3}$ Biomarkers and Clinical Research in Eating Disorders, Ballerup Center for Mental Health Services, Capitol Region of Denmark, Rigshospitalt-Ballerup, Denmark.}

Received: 19 July 2016 Accepted: 14 August 2017

Published online: 22 August 2017

\section{References}

1. International Agency for Research on Cancer (IARC). IARC Working Group on the Evaluation of Carcinogenic Risks to Humans. Tobacco smoke and involuntary smoking. IARC Work Gr Eval Carcinog Risks to Humans. 2004;83:8-11.

2. Secretan B, Straif K, Baan R, Grosse Y, El Ghissassi F, Bouvard V, et al. A review of human carcinogens-part E: tobacco, areca nut, alcohol, coal smoke, and salted fish. Lancet Oncol. 2009;10:1033-4.

3. United States Department of Health and Human Services. The Health Consequences of Smoking - 50 Years of Progress A Report of the Surgeon General. A Rep Surg Gen. 2014.

4. Baron JA, Vecchia C La, Levi F. The antiestrogenic effect of cigarette smoking in women. Am J Obs Gynecol 1990;162:502-514.

5. Collaborative Group on Hormonal Factors in Breast Cancer. Alcohol, tobacco and breast cancer-collaborative reanalysis of individual data from 53 epidemiological studies, including 58,515 women with breast cancer and 95,067 women without the disease. Br J Cancer. 2002;87:1234-45.

6. Xue F, Willett WC. Rosner B a, Hankinson SE, Michels KB. Cigarette smoking and the incidence of breast cancer. Arch Intern Med. 2011;171:125-33.

7. Luo J, Margolis KL, Wactawski-Wende J, Horn K, Messina C, Stefanick $\mathrm{ML}$, et al. Association of active and passive smoking with risk of breast cancer among postmenopausal women: a prospective cohort study. BMJ. 2011;342:d1016.

8. Rosenberg L, Boggs DA, Bethea TN, Wise LA, Adams-Campbell LL, Palmer JR. A prospective study of smoking and breast cancer risk among AfricanAmerican women. Cancer Causes Control. 2013;24:2207-15.

9. Bjerkaas E, Parajuli R, Weiderpass E, Engeland A, Maskarinec G, Selmer R, et al. Smoking duration before first childbirth : an emerging risk factor for 
breast cancer? Results from 302,865 Norwegian women. Cancer Causes Control. 2013:1347-56.

10. Gaudet MM, Gapstur SM, Sun J, Diver WR, Hannan LM, Thun MJ. Active smoking and breast cancer risk : original cohort data and meta-analysis. J Natl Cancer Inst. 2013:515-25.

11. Dossus L, Boutron-Ruault M-C, Kaaks R, Gram IT, Vilier A, Fervers B, et al. Active and passive cigarette smoking and breast cancer risk: results from the EPIC cohort. Int J Cancer. 2014;134:1871-88.

12. Catsburg C, Miller AB, Rohan TE. Active cigarette smoking and risk of breast cancer. Int J Cancer 2015;2209:2204-2209.

13. Nyante SJ, Gierach GL, Dallal CM, Freedman ND, Park Y, Danforth KN, et al, Cigarette smoking and postmenopausal breast cancer risk in a prospective cohort. Br J Cancer. 2014;110:2339-47.

14. Nishino Y, Minami Y, Kawai M, Fukamachi K, Sato I, Ohuchi N, et al. Cigarette smoking and breast cancer risk in relation to joint estrogen and progesterone receptor status: a case-control study in Japan. Spring. 2014;3:65.

15. Catsburg C, Kirsh VA, Soskolne CL, Kreiger N, Rohan TE. Active cigarette smoking and the risk of breast cancer: a cohort study. Cancer Epidemiol. 2014;38:376-81.

16. Ewertz M. Smoking and breast cancer risk in Denmark. Cancer Causes Control. 1990;1:31-7

17. Bennicke K, Conrad C, Sabroe S, Sørensen HT. Cigarette smoking and breast cancer. BMJ. 1995;310:1431-3.

18. Hundrup YA, Simonsen MK, Jørgensen T, Obel EB. Cohort profile: the danish nurse cohort. Int J Epidemiol. 2012;41:1241-7.

19. Pedersen CB. The Danish civil registration system. Scand J Public Heal. 2011;39:22-5.

20. Gjerstorff ML. The Danish cancer registry. Scand J Public Heal. 2011;39:42-5.

21. Møller S, Jensen M, Ejlertsen B, Bjerre KD, Hansen HB, Christiansen P, et al. The clinical database and the treatment guidelines of the Danish breast cancer cooperative group (DBCG); its 30-years experience and future promise. Acta Oncol. 2009;47:506-24.

22. Hess KR. Graphical methods for assessing violations of the proportional hazards assumption in cox regression. Stat Med. 1995;14:1707-23.

23. Tjønneland A, Olsen A, Boll K, Stripp C, Christensen J, Engholm G, et al. Study design, exposure variables, and socioeconomic determinants of participation in diet, cancer and health: a population-based prospective cohort study of 57,053 men and women in Denmark. Scand J Public Heal. 2007:35:432-41.

24. Lanigan F, O'Connor D, Martin F, Gallagher WM. Molecular links between mammary gland development and breast cancer. Cell Mol Life Sci. 2007;64: 3159-84.

25. Russo J, Mailo D, Hu YF, Balogh G, Sheriff F, Russo IH, et al. Breast' differentiation and its implication in cancer prevention. Clin Cancer Res. 2005;11:931s-6s.

26. Mørch LS, Johansen D, Thygesen LC, Tjønneland A, Løkkegaard E, Stahlberg $C$, et al. Alcohol drinking, consumption patterns and breast cancer among Danish nurses: a cohort study. Eur J Public Heal. 2007;17:624-9.

27. Stahlberg C, Pedersen AT, Lynge E, Andersen ZJ, Keiding N, Hundrup YA, et al. Increased risk of breast cancer following different regimens of hormone replacement therapy frequently used in Europe. Int I Cancer 2004:109:721-7.

28. Stahlberg C. Pedersen a T, Andersen ZJ, Keiding N, Hundrup Y a, Obel $E B$, et al. breast cancer with different prognostic characteristics developing in Danish women using hormone replacement therapy. Br J Cancer. 2004;91:644-50.

29. Jacobsen KK, Lynge E, Vejborg I, Tjønneland A, von Euler-Chelpin M, Andersen ZJ. Cigarette smoking and mammographic density in the Danish diet, cancer and health cohort. Cancer Causes Control. 2016;27:271-80.

\section{Submit your next manuscript to BioMed Central and we will help you at every step:}

- We accept pre-submission inquiries

- Our selector tool helps you to find the most relevant journal

- We provide round the clock customer support

- Convenient online submission

- Thorough peer review

- Inclusion in PubMed and all major indexing services

- Maximum visibility for your research

Submit your manuscript at www.biomedcentral.com/submit
C Biomed Central 